\title{
Anomalous single coronary artery accompanied by accessory mammary tissue presenting with typical angina pectoris
}

\author{
Tipik angina pektorisle başvuran tek koroner arter anomalisi ve aksesuar meme \\ dokusu birlikteliği
}

\author{
Hakkı Kaya*, Hasan Yücel, Ali Zorlu, Utku Kütük, Orhan Doğdu \\ Cardiology Clinic (H. Kaya, MD, U. Kütük, MD), Sivas Numune Hospital, TR-58100 Sivas, \\ Department of Cardiology (Prof. H. Yücel, MD, Assist. Prof. A. Zorlu, MD), Cumhuriyet \\ University School of Medicine, TR-58140 Sivas, Department of Cardiology (Assist. Prof. O. \\ Doğdu, MD), Firat University School of Medicine, TR-23200 Elazı̆
}

\begin{abstract}
Single coronary artery is described as an isolated coronary artery originating from the aortic root through a single ostium in the absence of another ostium. The single coronary artery is the only source for blood supply to the whole heart. In this case we present a patient admitted to the outpatient clinic with typical chest pain, whose physical examination indicated accessory mammary tissue without any additional physical examination findings. The patient had hyperlipidemia and hypertension risk factors, and a coronary angiography was planned. The coronary angiography performed on the 72 year old male patient revealed a single coronary artery. According to the angiography, it is reported that the whole coronary system is distributed to the heart from a single trunk originating from the right sinus of valsalva. The multislice computerized tomography showed that the left anterior descending, circumflex and right coronary arteries originated from single trunk at the level of right sinus of valsalva through a single ostium without the left main trunk. There was no additional congenital anomaly. The patient, who had noncritical strictures, was discharged with medical treatment. Neural crest cells, matrix metalloproteinase, epidermal growth factor receptors, vascular endothelial growth factor and receptors are effective in the development of coronary arteries and mammary tissues in the embryonic phase. Any impact on the migration routes of the neural crest cells or distortion of the synthesis of expression products may have caused this kind of an anomaly.
\end{abstract}

Keywords: Coronary artery anomaly, accessory mammary tissue, embryogenesis

\section{Özet}

Tek koroner arter, aort kökünden tek koroner ostiyum aracılığıyla çıkan ve ikinci bir ostiyumun gözlenmediği izole koroner arter olarak tanımlanır. Tek koroner arter bütün kalbin kan akımının sağlanmasından sorumludur. Bu olguda, tipik göğüs ağrısı nedeniyle polikliniğe başvuran, fizik muayenesinde aksesuar meme dokusu olan ve ek fizik muayene bulgusu olmayan bir hasta sunuldu. Hiperlipidemi ve hipertansiyon risk faktörleri olan hastaya koroner anjiyografi planlandi. Yapılan koroner anjiyografide tek koroner arter saptanan 72 yaşında erkek hasta sunuldu. Koroner anjiyografide tüm koroner sistemin să sinüs valsalva'dan çıkan tek gövdeden kalp bölgesine yayılım gösterdiği saptandı. Çokkesitli bilgisayarlı tomografide, sol ön inen, sirkumfleks ve sağ koroner arterlerin sol ana gövde olmaksızın tek ostiyum aracılığı ile sağ sinüs Valsalva düzeyinde tek gövdeden köken aldıkları izlendi. Ek konjenital anomali izlenmedi. Nonkritik darlıkları olan hasta medikal tedavi ile taburcu edildi. Koroner arter ve meme dokusunun embriyonal dönemde gelişmesinde, nöral krista hücreleri, matriks metalloproteinazlar, epidermal büyüme faktör reseptörleri, vasküler endotelyal büyüme faktörü ve reseptörleri etkilidir. Nöral krista hücrelerinin göç yollarının etkilenmesi ya da ekspresyon ürünlerinin sentezlenmesindeki bir aksaklık bu tür bir anomali oluşmasına yol açmış olabilir.

Anahtar sözcükler: Koroner arter anomalisi, aksesuar meme dokusu, embriyogenez 
Geliş tarihi/Received: April 09, 2014; Kabul tarihi/Accepted: June 13, 2014

\section{*Corresponding author:}

Dr. Hakkı Kaya, Kardiyooji Kliniği, Sivas Numune Hastanesi, TR-58100 Sivas. E-mail: drhakkikaya84@gmail.com

\section{Introduction}

Coronary artery anomalies, which are mostly coincidentally diagnosed during routine coronary angiography, have a prevalence of $0.6-1.3 \%$ [1]. The prevalence of coronary artery anomalies diagnosed at coronary angiography is reported to be $0.5-1 \%$ [2]. Single coronary artery is described as an isolated coronary artery originating from the aortic root through a single ostium in the absence of another ostium. The prevalence of single coronary artery anomaly in the society is found to be $0.02 \%$ [3]. Generally it does not present any signs and has a good prognosis. However, some types of single coronary artery may cause serious cardiac events such as sudden death and myocardial infarction particularly during exercise. Moreover, isolated single coronary artery anomaly can present clinical tables such as chest pain, arrhythmia, fainting and congestive heart failure [4].

The prevalence of accessory mammary tissue, on the other hand, is about 2-6\%. Approximately, in the sixth week, a band type mammary line composed of ectoderm extending from axilla to groin in both sides of the body is observed in the embryo. Accessory mammary tissue is formed as a result of some persistent pieces of the mammary line. Most commonly it is seen in the axillary region [5]. There are various factors that play a role concomitantly in the development of the mammary tissue and coronary arteries in the embryonic phase. Some of them are neural crest cells, matrix metalloproteinase (MMP), epidermal growth factor receptors (ErbB4), vascular endothelial growth factor (VEGF) and its receptors [6].

In this article we present a case, who is admitted with typical chest pain, with accessory mammary tissue defined in the physical examination, and anomalous coronary artery originating from single trunk at the level of right sinus of valsalva.

\section{Case report}

A 72 year old male patient came to our outpatient clinic with typical chest pain. The patient had hypertension and hyperlipidemia as a coronary artery risk factor, however he was not receiving any regular medical treatment. According to his physical examination, the blood pressure was $160 / 100 \mathrm{mmHg}$, heart rate $68 / \mathrm{min}$ and stable and the systemic examination revealed an accessory mammary tissues in addition to the normal mammary tissue (Figure 1).

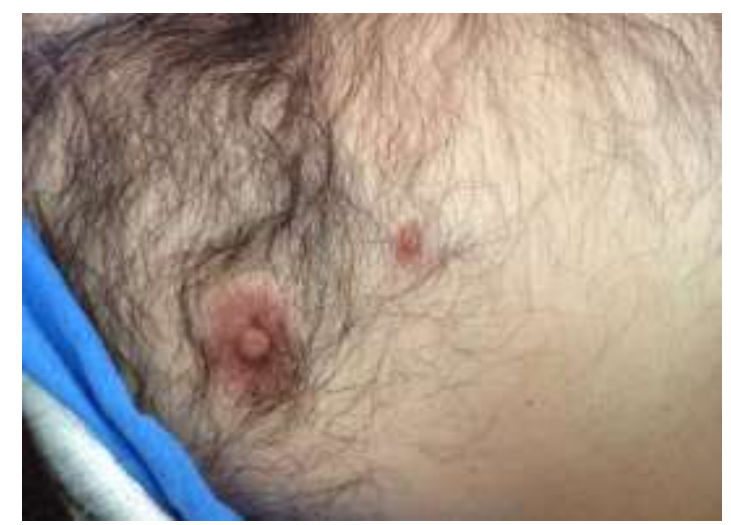

Figure 1. Accessory mammary tissues in addition to the normal mammary tissue. 
His electrocardiography showed $\mathrm{T}$ wave negativity, which is not specific to anterior derivations. Coronary angiography was performed and it was observed that there was a single coronary artery originating from the right sinus of valsalva (Figure 2).

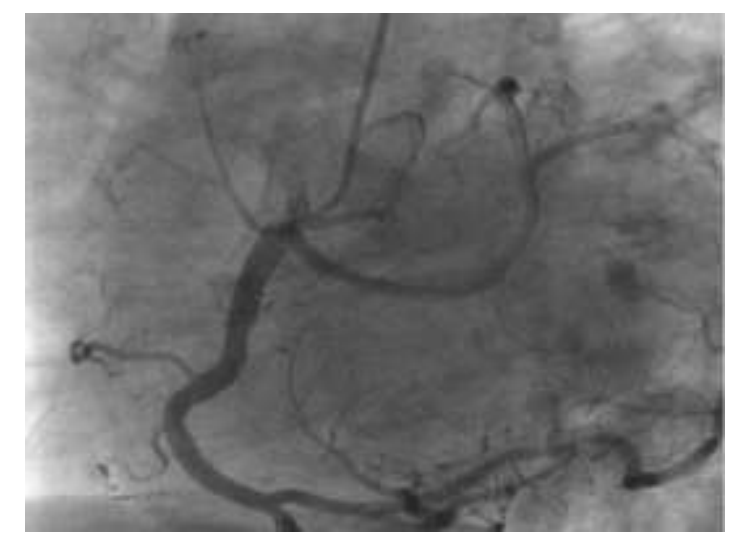

Figure 2. Single coronary artery originating from the right sinus of valsalva.

Multislice computerized tomography was ordered to better evaluate the path of the coronary arteries and to investigate whether there were any additional congenital disorders, and the CT revealed that the left anterior descending (LAD), circumflex and right coronary arteries were originating from a single trunk at the level of the right sinus of valsalva through single ostium without the left main trunk. The right coronary artery was following a normal path without any stenosis and its diameter was natural. The left anterior descending artery was travelling forward and upwards from the trunk and then turned left just after the anterior of the pulmonary trunk and reached its normal track. The circumflex artery, on the other hand, extended towards left just in the posterior part of the trunk, between the aortic root and left atrium, and followed its normal track. The patient was discharged with medical treatment.

\section{Discussion}

Most of the congenital coronary artery anomalies do not present any indications and they are coincidentally diagnosed during angiography [1]. There is no information available in the literature about coronary artery anomaly accompanied by accessory mammary tissue. The vascular system of the heart develops on the basis of three components during embryogenesis. The first component is formed in the fourth week from the intertrabecular groove. These grooves run from the ventricular cavity along the trabecula in the form of an endothelial line. The vascular system of the heart starts to compose on the epicardial surface of myocardium together with the increase in the wall thickness of the heart at the beginning of the post-somitic period (the third week) [7]. In the sixth week, sinus venosus develops from the middle cardiac vein. Coronary arteries develop from bulbus cordis by forming buds. The budding at the right coronary artery extends towards the sulcus lying between the pulmonary conus, right ventricle and right appendage, and then at the level of the crux of the heart, it travels to the diaphragmatic surface. Throughout this course, it provides muscular branches to the right and left ventricles. The left coronary artery, on the other hand, buds from the aorta. It then passes from behind the pulmonary truncus and under the left atrial appendage. It gives off large branches to the interventricular sulcus and circumflex artery to the left atrioventricular sulcus. The branches coming off from the main coronary arteries penetrate to the myocardium and create anastomoses in the intertrabecular groove.

Vascular smooth muscle cells and adventitial fibroblasts originate from epithelialmesenchymal transition of epicardial mesothelium. Precursor cells of coronary endothelium are epicardium-derived cells. These cells can differentiate into endothelium cells with the effect of the vascular endothelial growth factor (VEGF) that is released from myocardium at an early phase and into smooth muscle cells or pericytes with the 
effect of platelet-derived growth factor (PDGF- $\beta$ ) [6]. Origin areas of coronary arteries are abundant in VEGF receptor-2 and VEGF receptor-3. This area, which is occupied with epicardial and subepicardial cells, presents an intense VEGF immunolocalization [6]. For that reason, VEGF and its receptors play critical role in the development of coronary artery systems [6]. VEGF and it receptors are also active in the intercellular interaction and angiogenesis of mammary development during the embryonic phase [6].

In the development of mammary tissue during the embryonic phase, ErbB4 is significant for lobuloalveolar development [6]. ErbB4 is also active in the development of heart and brain at the same time. In addition, ErbB4 defines the migration of neural crest cells, which play an effective role in the development of coronary arteries [6]. Any distortion at the regional migration of neural crest cells in the embryonic phase will have an effect on the development of coronary arteries. Neural crest cells are important for the normal development of coronary arteries and arteries originating from the aortic arc. Otherwise, various anomalies will be inevitable [8]. Matrix metalloproteinases (MMPs) have immense impact on the morphogenesis of the mammary gland in the embryonic phase. MMPs have also a role to play in the epithelial mesenchymal transition related to cell migration and tissue morphogenesis. MMPs regulate neural crest delamination, endocardial cushion invasion and morphogenesis of the mammary gland [6].

Metalloproteinases are, under normal conditions, zinc-dependent endopeptidases, which form the extracellular matrix and regulate cellular activity through various means. By these means, MMPs ensure extracellular matrix degradation, cell adhesion, molecules that are segregated with extracellular matrix and transformation of cell surface proteins which transmit signals from extracellular medium. Uncontrolled expression of MMP causes tissue destruction [8]. Most commonly seen coronary artery anomalies are as follows; LAD and circumflex arteries originating from different ostia at the left sinus of Valsalva, circumflex artery originating from the right sinus of Valsalva or the right coronary artery, and coronary artery fistulas. Isolated single coronary artery anomaly is one of the least common coronary artery anomalies and composes $2-4 \%$ of all coronary artery anomalies $[3,9]$. Single coronary artery anomalies are classified according to the point of origin at the right or left coronary artery, to the anatomical distribution on the ventricle surface and to the association with the ascending aorta and pulmonary artery [9]. Our case is found to be in compliance with RIIIA classification. In this type of anomaly, if the coronary artery runs between the aorta and pulmonary artery, there is a high risk of sudden death. In addition, even if the artery does not extend between the aorta and pulmonary artery, it can still cause serious events; because the situation may lead to cardiac ischemia, congestive heart failure, ventricular fibrillation or sudden death [9]. Although atherosclerotic heart disease is less frequently seen in young patients with coronary anomalies vis a vis old patients, spontaneous sudden death or during exercise is much more common [10]. The prognosis of single coronary artery cases depend on the anatomic distribution. While there may be no problem observed in some portion of the patients during follow-up, sudden death may be encountered in some patients and about $15 \%$ of the patients can become symptomatic with serious cardiac problems below the age of 40 [6]. Under 20 mortality in cases with left coronary artery originating from right coronary sinus is higher (59\%). Death is often faced upon exhaustive physical activity; because the vessel, which has expanded under physical activity, gets stuck between the aorta and pulmonary artery [2]. If this path of the artery running from the right ventricle to the aorta is not treated surgically, the mortality risk will be high [10]. The age of the patient and the type of the anomaly are vital in the determination of treatment in asymptomatic patients. As regards symptomatic patients, however, if the course of the artery causes danger and if the patient is diagnosed at a young age, surgical treatment is necessary [10]. Taylor et al. [5] reported that the risk of sudden death was high (82\%) in single coronary artery patients with the left main coronary following an interarterial course $82(\%)$. In our case, the patient had typical chest pain and it was decided to follow up the patient upon relief by medical therapy. 
In conclusion, neural crest cells, MMP, ErbB4, VEGF and its receptors are effective in the development of coronary arteries and mammary tissues in the embryonic phase. Any impact on the migration routes of neural crest cells or a distortion of the synthesis of the abovementioned expression products may have caused such kind of an anomaly.

\section{References}

1. Yamanaka O, Hobbs RE. Coronary artery anomalies in 126.595 patients undergoing coronary arteriography.Cathet Cardiovasc Diagn 1990; 21: 28-40.

2. Angelini P, Velasco JA, Flam S. Coronary anomalies: Incidence, pathophysiology and clinical relevance. Circulation 2002;105: 2449-54.

3. Desmet W, Vanhaecke J, Vrolix M, Van de Werf F, Piessens J, Willems J. Isolated single coronary artery: A review of 50.000 consecutive coronary angiographies. Eur Heart J 1992; 13: 1637-40.

4. Frescura C, Basso C, Thiene G, Corrado D, Pennelli T, Angelini A. Anomalous origin of coronary arteriesand risk of sudden death: A study based on an autopsy population of congenital heart disease. Hum Pathol 1998; 29: 689-95.

5. Taylor AJ, Rogan KM, Virmani R. Sudden cardiac death associated with isolated congenital coronar yartery anomalies. J Am Coll Cardiol 1992; 20: 640-7.

6. Tidcombe H, Jackson-Fisher A, Mathers K, Stern DF, Gassman M, Golding JP. Neural and mammary gland defects in ErbB4 knockout mice genetically rescued from embryonic lethality, Developmental Biology 2003; 100: 8281-6.

7. Bernanke DH, Velkey JM, Development of the coronary blood supply: Changing concepts and current ideas. Anat. Rec 2002; 269: 198-08.

8. Tomanek RJ, Holifield JS, Reiter RS, Sandra A, Lin JJ. Role of VEGF family members and receptors in coronary vessel formation. Dev. Dyn 2002; 225: 23340.

9. Lipton MJ, Barry WH, Obrez I, Silverman JF, Wexler L. Isolated single coronary artery: Diagnosis, angiographicclassification, and clinical significance. Radiology 1979; 130: 39-47.

10. Popma JJ. Coronary angiography and intravascular imaging. In: Zipes DP, Libby P, Bonow RO, Braunwald E, editors. Heart disease: A textbook of cardiovascularmedicine. 7th ed. Philadelphia: Elsevier Saunders 2005; 423-55. 